\title{
Psychological well-being and their relationship with different referents and sources of happiness in Chile ${ }^{1}$
}

\author{
Emilio Moyano-Diaz ${ }^{2}$, Rodolfo Mendoza-Llanos ${ }^{3}$, Darío Paez-Rovira ${ }^{4}$ \\ Universidad de Talca-Chile ${ }^{2}$, Universidad del Bio-Bio-Chile', Universidad \\ Andrés Bello-Chilé, Universidad del País Vasco-España ${ }^{4}$
}

\begin{abstract}
The association between nine philosophical referents of happiness and well-being was examined in a convenience sample $(n=1060)$ of two Chilean cities. Participants had to choose one referent and respond to well-being, satisfaction, and happiness scales regarding family, friends, work, and leisure. A lower educational level was associated more with the referents Tranquility and Stoicism and less with the realization of capabilities. Young people ascribe more to the referents Satisfaction and Carpe Diem. Multiple hierarchical regressions considering well-being as a predicted variable showed that the Satisfaction and Affiliation referents were associated with greater psychological well-being. These results and the differences between the happiness referents chosen according to the controlled variables are discussed. Keywords: well-being; eudemonic; referents of happiness
\end{abstract}

Bienestar psicológico y su relación con referentes y fuentes de felicidad en Chile Se examinó la asociación entre nueve referentes filosóficos de felicidad con el bienestar, en una muestra de conveniencia $(n=1060)$ de dos ciudades chilenas. Los participantes debían elegir un referente y responder escalas de bienestar, de satisfacción y de felicidad respecto de la familia, amigos, trabajo y ocio. Menor nivel educativo se asoció más a los referentes Tranquilidad y Estoicismo, y menos al de Realización de capacidades. Los jóvenes adscriben más a los referentes Satisfacción y Carpe Diem. Regresiones múltiples jerárquicas considerando el bienestar como variable predicha mostraron los referentes Satisfacción y Afiliación

1 This research was funded by the National Fund for Scientific and Technological Development from the Chilean Government, FONDECYT No. 1170855 (ANID) to the first author; Universidad del Bío-Bío (DIUBB 167824 2/I); Culture, Cognition and Emotion; the University of the Basque Country and Basque Govern [grant number Ref. IT-1187-19] and Culture, Coping and Emotional Regulation: Life and collective gatherings [grant number PSI2017-84145-P].

2 PhD. by Université Catholique de Louvain. Professor in Universidad de Talca (Chile). Postal address: Facultad de Psicología, Universidad de Talca, Campus Lircay s/nº, Talca, Chile. Contact: emoyano@utalca.cl

3 PhD. by Universidad de Talca. Assistant Professor in Universidad del Bío-Bío (Chile). Postal address: Escuela de Psicología, Universidad del Bío-Bío, Andrés Bello 720, Chillán, Chile. Contact: rmendoza@ubiobio.cl

4 PhD. by Université Catholique de Louvain. Professor in Universidad del País Vasco and Universidad Andrés Bello. Postal Address: Departamento de Psicología Social y Metodología, Universidad del País Vasco, San Sebastián 20018, España. Contact: dario.paez@ehu.es 
asociados a mayor bienestar psicológico. Se discuten estos resultados y las diferencias entre los referentes de felicidad elegidos según las variables controladas.

Palabras clave: bienestar, eudaimónico, referentes de felicidad.

Bem-estar psicológico e sua relação com referentes e fontes de felicidade no Chile

A associação entre nove referentes filosóficos de felicidade e bem-estar foi examinada em uma amostra de conveniência $(n=1060)$ de duas cidades chilenas. Os participantes tiveram que escolher um referente e responder às escalas de bem-estar, satisfação e felicidade em relação à família, amigos, trabalho e lazer. $\mathrm{O}$ menor nível educacional foi associado mais aos referentes Tranquilidade e Estoicismo, e menos à Realização de Capacidades. Os jovens escolhem mais os referentes Satisfação e Carpe Diem. Regressôes hierárquicas múltiplas, considerando o bem-estar como variável prevista, mostraram os referentes Satisfação e Afiliação associados a um maior bem-estar psicológico. Estes resultados e as diferenças entre os referentes de felicidade escolhidos são discutidos em relação às variáveis controladas.

Palavras-chave: bem-estar, eudaimônico, referentes à felicidade.

\section{Le bien-être psychologique et sa relation avec les référents et les sources de bonheur au Chili}

L'association entre neuf référentes philosophiques du bonheur et du bien-être ont été examinés dans un échantillon de convenance $(n=1060)$ de deux villes chiliennes. Les participants devaient choisir un référente et répondre à des échelles de bien-être, de satisfaction et de bonheur concernant la famille, les amis, le travail et les loisirs. Le niveau d'éducation inférieur était davantage associé aux référents Tranquillité et Stoïcisme, et moins à la Réalisation des Capacités. Les jeunes chosent plus les référentes Satisfaction et Carpe Diem. De multiples régressions hiérarchiques considérant le bien-être comme variable prédite ont montré aux référents Satisfaction et Affiliation associés à un plus grand bien-être psychologique. Ces résultats et les différences entre les référents choisis en fonction des variables contrôlées sont discutés.

Mots-clés : bien-être, eudaimonique, référents du bonheur 
Rojas (2005) proposed the conceptual referent theory of happiness (CRT) for understanding the mental framework, or the general cultural conception about happiness, that people have when asked about how happy they are (Rojas \& Vitterso, 2010; Rojas \& Veenhoven, 2013). CRT states that people differ in their conceptual referents about happiness, and this plays a significant role in their judgment of happiness and satisfaction with life. The measure for happiness comes from a cognitive evaluation based on these cultural models, lay beliefs, conceptions, or ideal standards about a happy life. The conceptual referents are based on ideals that have a role in happiness and more broadly to well-being. These referents frame the cognitive judgment that estimates the difference between a real personal state and an ideal of happiness (Rojas \& Veenhoven, 2013). These referents are conceptually related to the cultural models (Holland \& Quinn, 1987), yet they are not prototypical scripts. Rather, they are abstract semantic models of a happy life acting as sociocultural premises (Díaz-Guerrero, 1984).

Certain In the process of stating the relevance of certain sociocultural premises for well-being have important relevance. in happiness. Some cross-cultural studies on ideal feelings showed that the individualistic North Americans relate happiness to states of high positive excitement like euphoria, enthusiasm, and thrill; whereas the Chinese, who are hierarchical collectivists, define happiness through states of lower positive excitement like calmness and relaxation. This suggests that cultural individualism conceives happiness as high positive emotionality, whereas Asian collectivism of a Confucian background defines happiness as balance and moderation (Tsai \& Park, 2014). Considering the variability in cultural differences towards happiness, eight synthesis phrases were elaborated for referring to the eight classical philosophical conceptions about happiness (Rojas \& Vitterso, 2012; Rojas \& Veenhoven, 2013). 
The eight referents can be classified into two categories: inner-oriented and outer-oriented. In the first type, there are Stoicism, Virtue, Utopia, and Tranquility. Stoicism views happiness as a permanent state of satisfaction with life and with what happens in it. Virtue considers happiness as a spiritual state produced by the sensation of acting per one's consciousness and moral duties. Utopia states that happiness is an ideal that guides human action. It is the perfection per se, synthesis of virtue and pleasure. It is a sort of good desired, yet unreachable, at least in this life. Tranquility considers happiness as a state of calmness and the absence of worries that can exist in a place with prudence, moderation, measurement, and judgmental desires. These referents contemplate someone emphasizing a mental attitude of acceptance, normativity, self-critique, and moderation.

In the second type, there are Enjoyment, Satisfaction, Carpe Diem, and Fulfillment. Enjoyment considers that happiness is joy, cheerfulness, and the absence of pain, enjoying these things grants comfort. It is the satisfaction of all human necessities and desires. Satisfaction views happiness as a sensation of euphoria about life that comes along with an intuitive judgment about oneself and the surrounding world. Carpe Diem considers that happiness lies in pleasure and current satisfaction. It is about enjoying as much as possible. Fulfillment states that happiness is the completion of our nature and our essence as human beings. Happiness lies in the activities that lead to the ultimate goal of every human being. All these emphasize the relation of the person with gratification and self-fulfillment (Rojas, 2005; 2007; Rojas \& Vitterso, 2010).

In this study, the referent of happiness Affiliation is added as the ninth referent to the list of eight referents from the classic philosophy of Rojas (2005). This referent has been operationalized-synthesized here with the following sentence: "Happiness is to share or to be with others." This is also outer-oriented. Different studies conducted with Latin American populations (Rojas, 2018; Yamamoto, 2015) show that family and community bonding, typical of collectivist societies, are very relevant. This centrality in Affiliation is linked to a higher 
expression of positive emotions that is typical of scenarios with socially engaged "sympathetic" or "simpático" interaction. This feature of Latin American culture suggests that this referent of happiness (Affiliation) is of high validity in our culture (Rojas, 2018; Fernández et al., 2000; Triandis et al., 1984). Previous studies for the Chilean population show that in both middle-class (Moyano-Díaz et al., 2018) and workingclass sectors (Hernández et al., 2017), family rises as a main factor for happiness (having family, maintaining harmonic relationships among members, family progress, etc.). It is expected that this referent will become associated with global or remembered happiness assessed by the Subjective Happiness Scale (SHS) and well-being assessed by the Pemberton Happiness Index (PHI). It is also expected that Affiliation along with Satisfaction, Enjoyment, Carpe Diem (to a small extent), Virtue, and Tranquility will be associated with higher happiness and well-being. However, the opposite will happen with Utopia (Rojas, 2005; Rojas \& Vitterso, 2010).

Stoicism and Tranquility belong to the inner-oriented type and are probably linked to self-control and calm, similar to the collectivist Asian ideal of balance and moderation (Tsai \& Park, 2014). A study conducted with Mexicans showed that people with a low income and educational level generally shared more collectivist values (Wink, 1997), agreeing more with Stoicism and Tranquility (Rojas, 2005). This data converges with results from other studies showing that in Chile the working class has a more realistic vision of what they consider as happiness (Hernández et al., 2017).

In turn, Enjoyment, Satisfaction (hedonism), and Fulfillment (outer-oriented) which are associated to a high hedonic well-being and self-fulfillment or eudaimonic psychological well-being, are probably more associated to individualism considering that they are related to high hedonic well-being and self-fulfillment or eudaimonic psychological well-being (Diener \& Suh, 2000). A study found that people with a high income and educational level agreed more with Satisfaction (hedonism) and Fulfillment (Rojas, 2005). This partially supports the association between individualism and its agreement to hedonistic and 
eudemonistic cultural ideals about happiness. This is because people of a higher social status are frequently more individualistic, while people of lower social status are more collectivistic (Marshall, 1997).

Concerning the life cycle, it has been observed that the older the person is, the more he or she will agree with Tranquility and Virtue. This means a more weighted vision of happiness and fulfilling moral ideals concerning happiness (Rojas, 2005, Rojas and Vitterso, 2010). These results are also congruent with previous studies showing that low neuroticism and conscientiousness increase with age (Costa \& McCrae, 2006). Young people in turn relate more to Carpe Diem and Satisfaction. This emphasis of living and accepting experiences is coherent with the life cycle phase where they currently find themselves (Sobol-Kwapinska, 2013). Young people also agree more with happiness as Fulfillment, reporting higher personal growth than adults and the elderly. Personal growth generally implies self-fulfillment and the development of personal capabilities (Ryff et al., 2003, but see Springer et al., 2009).

Regarding the relation between referents for happiness and wellbeing, Mexicans, Cubans, Norwegians, and South-Africans that share the referents Satisfaction and Enjoyment reported greater happiness (Rojas, 2005; Rojas \& Vitterso, 2010). Some studies showed that Utopia was associated with lower happiness, whereas Carpe Diem was associated with higher happiness (Rojas, 2005; 2007; Rojas \& Vitterso, $2010)^{5}$. A shared conception about happiness that emphasizes the referent Satisfaction, along with positive acceptance from the person and of the circumstances, will probably reinforce well-being (Diener \& Suh, 2000). A hedonistic conception of happiness with an emphasis on delight, the absence of pain, and the enjoyment of positive experiences will also orient people towards experiencing higher well-being (Lyu-

5 We ran a meta-analytical integration of the Rojas \& Vitterso (2010) study that correlates degree of agreement with happiness referents and happiness. Effects size $(\mathrm{N}=446$ Norway, Cuba, and South Africa) were $r$ weighted $=.22$ Enjoyment with Happiness; $r$ weighted $=.19$ Satisfaction with Happiness; $r$ weighted $=.11$ Utopian with Happiness; $r$ weighted $=.27$ Carpe Diem with Happiness, all significant CI excluding zero - random model coefficients. 
bomirsky, 2008). On the other hand, a conception of happiness such as Utopia will probably be associated with a more critical vision about their environment, yet generate more well-being (Rojas, 2007). Finally, the conception of happiness such as Carpe Diem also brings awareness about death and to the ephemeral part of life; this is a mixture of negative and positive feelings (Rojas, 2007). In fact, it was found in a Mexican sample that those who share this referent report less happiness than the people who agree with Satisfaction, Enjoyment, and less happiness than those who identify with the referent Tranquility. This suggests that Tranquility is associated with happiness in some samples (Rojas, 2005). Tranquility, as previously described, has at its core the absence of worries and moderation, and it seems to be an ideal that belongs to the Confucian and collectivist morality (Tsai \& Park, 2014). Hence, it implies a certain attitude close to mindfulness and the acceptance of life just as it presents itself. This probably would reinforce certain emotional well-being and have a low activation rate in collectivist cultures (Rojas \& Vitterso, 2010).

In addition to evaluating satisfaction and happiness as general constructs, four areas of human functioning were considered: family, work, friends, and leisure. Identifying the level of satisfaction and happiness by areas is important, but we also believe that it impacts and contributes to explaining global satisfaction and happiness. It is expected that family will be the area of greatest influence over well-being and happiness, followed by work, leisure, and friends (Moyano \& Ramos, 2007). Likewise, strong associations between family and work with well-being, and between friends and leisure with happiness are also expected to be found.

Finally, it is important to point out that daily feelings could be related to certain well-being answers. There is a difference between remembered well-being, which is based on global judgment and evaluations of the past, and lived well-being in recent moments (Kahnemman, 2012). The latter is assessed through items that measure the previous day's positive and negative feelings. This kind of lived wellbeing is associated less with social variables and personal dispositions 
in the long term than the remembered, and it is strongly associated with recent circumstantial changes (Kahnemann, 2012; Helliwell et al., 2018). However, this current or recent lived well-being "influences the perception people have of remembered well-being (of the past)." Research about the effects of the mood's congruence over judgment suggests that individuals make use of their affective states as relevant information for evaluation tasks such as self-description and satisfaction about life (Schwarz \& Strack, 1999; Sedikides, 1995). For example, in the study by Páez et al. (2013), the previous day's positive and negative feelings were associated congruently with hedonistic and eudemonistic well-being.

Considering the evidence from the preceding literature, in the present study the following hypotheses are examined:

H1. Low level of education (as a proxy of social class) will be related to Stoicism and Tranquility.

H2. High level of education (as a proxy of social class) will be associated with Satisfaction (hedonism) and Fulfillment.

H3. Older participants will agree more with the Tranquility and Virtue referents.

H4. Younger participants will opt for the referents of happiness Carpe Diem and Satisfaction.

H5. Participants who choose the referents Satisfaction, Enjoyment (hedonism), Affiliation (sociability), Carpe Diem (to a small extent), Virtue, and Tranquility will report higher well-being.

H6. Among the areas of operation of the participants, family will be the source that most influences their well-being.

H7. There will be a gradual or decreasing impact of family, work, leisure, and friends on the well-being of the participants. 


\section{Method}

\section{Participants}

The sample consisted of 1,060 Chilean adults of both sexes (50.4\% women). Most were workers (95\%) with an average age of 36.7 years; ages ranged from 18 to 80 years old. Thirty-five percent of the sample had a university education, $23.9 \%$ had a post-secondary education (not university), 33.7\% completed secondary school, and 7.2\% completed only primary school. This sample included working adults in all kinds of fields (security guards, unskilled laborers, police officers, cashiers, teachers, micro-entrepreneurs, businesspeople, among others); only 5\% (55) were students.

\section{Measures}

Three different instruments were used to measure the referents, or sociocultural premises, of happiness, well-being, and the importance and satisfaction regarding the four areas of human functioning and sources of happiness.

Happiness Referents Scale (Rojas, 2005): It identifies the philosophical concepts of happiness of the respondent. It uses eight statements based on eight different philosophical schools regarding happiness.

Pemberton Happiness Index (PHI) (Hervas \& Vázquez, 2013): It measures two main types of well-being (hedonic and eudemonic,) and also measures social well-being (21 items). It distinguishes one dimension of remembered well-being (past) with 11 items (e.g., 'I feel very satisfied with my life') that are answered using a Likert scale, from 0 (totally disagree) to 10 (totally agree). It also considers lived well-being (present) with 10 items (5 for positive affection and 5 for negative) that are answered in a dichotomic scale (where $1=$ yes, or presence, and 0 = no, or absence) (e.g., about positive lived well-being, 'I had a fun time with somebody' and negative 'Things happened that made me very angry'). This last one includes the evaluation of the positive or negative 
feelings of the day before the test. Reliability for remembered wellbeing is very satisfactory in samples from different countries (Hervás \& Vásquez, 2013), including Chilean samples. The same applies to the examined structural validity through validity confirmatory analysis. Martínez-Zelaya et al. (2018) reported for Latin American samples a reliability alpha $=.81$ for remembered well-being, Küder Richardson .71 for positive feelings, and .74 for negative feelings.

Scale for Sources of Happiness and Satisfaction (Moyano \& Ramos, 2007): It contains four reactive items (one per area) for assessing the degree to which the participants believe their happiness comes from family, work, leisure, and friends. For this task, the Likert scale of 1 to 7 was used, where $1=$ "Strongly disagree"; and $7=$ "Completely agree", for instance, "Working activity is the main source of happiness for people". Similarly, self-reported levels of satisfaction were assessed in these four areas. The domain value was multiplied with the satisfaction to estimate the importance of this source of happiness.

\section{Procedure}

The instruments were applied to the participants preceded by an explanation about the aim of the study, the absence of risks and benefits, and the autonomy of participation in the study.

Participants $(1,200)$ answered surveys including the scales were administered by psychologists. Here, the previous day's emotions were measured by the experienced well-being of the PHI and were used for controlling the influence of recent feelings about judgments of happiness and psychological well-being. Hence, they were included as predictors in the last step. Participants were asked to choose the statement that best represented their own notion about happiness. The nine referent-phrases were presented in the following way: "Happiness can have different meanings for different people. Please choose among the following nine statements the one that best represents what happiness is for you or that you most identify with." 


\section{Data analyses}

The reporting of results will begin by presenting descriptive results regarding the referents for happiness using SPSS 25. Later, referents were correlated with well-being, socio-demographic variables, and satisfaction regarding the four human functioning areas. A hierarchic regression model was carried out. In the first step, the dependent variables (PHI) were predicted in a regression based on age, sex, educational level, and eight dummy variables for the conceptual referents for happiness, leaving one of the nine as a comparison variable. In the second step, satisfaction with the four areas of human functioning (work, family, friends, and leisure) were added as predictors. Finally, the previous day's feelings were included in the third step. For these incremental validity analyses, the adjusted squared multiple average correlations are shown as evaluation criteria coefficients $\left(R_{\text {adjusted }}^{2}\right)$.

\section{Results}

\section{Descriptive Results regarding Conceptual Referents for Happiness}

The percentage distribution of participants is presented according to the participants' selection of conceptual referents for happiness (see Table 1) and compared with the corresponding Mexican sample (Rojas, 2005). Additionally, it has been added to the happiness average (SHS) and associated to each referent classified as inner- or outer-oriented, according to Rojas study (2005). 


\section{Table 1}

Conceptual referents with their percentage distribution for Mexican $(n=1452)$ and Chilean $(n=1027)$ samples. The Affiliation or $9^{\text {th }}$ referent for the Chilean study is also included

\begin{tabular}{lccc}
\hline & Mexican & \multicolumn{2}{c}{ Chilean sample } \\
\cline { 3 - 4 } Conceptual Referent & sample & $\begin{array}{c}8 \text { referents } \\
(n=920) \%\end{array}$ & $\begin{array}{c}9 \text { referents } \\
(n=1018) \%\end{array}$ \\
\hline Stoicism & 14.6 & 5.0 & 4.5 \\
Virtue & 8.2 & 7.4 & 6.7 \\
Utopia & 7.7 & 12.8 & 11.6 \\
Tranquility & 8.1 & 6.4 & 5.8 \\
Fulfillment & 11.7 & 10.4 & 9.4 \\
Satisfaction & 24.2 & 35.5 & 32.1 \\
Carpe Diem & 11.6 & 10.1 & 9.1 \\
Enjoyment & 14.0 & 12.3 & 11.1 \\
Affiliation & --- & --- & 9.6 \\
Total & 100.0 & 100.0 & 100.0 \\
\hline
\end{tabular}

Mexican sample corresponds to Rojas' (2005) study. 8 referents = original referents proposed by Rojas (2005). 9 referents = correspond to 8 referents plus Affiliation, included in this study.

\section{Point Biserial correlation between conceptual referents, well-being, and socio-demographic variables}

For examining the specific differences, a point Biserial correlation was calculated using the choice of a referent (Yes = $1, \mathrm{No}_{=} 0$ ), the wellbeing variables, sources for happiness, sex, age, and education.

These analyses allow contrasting the hypothesis relative to the association of educational level (proxy of social class) (H1 and H2), age (H3 and H4), and well-being with the conceptual referents. 


\section{Table 2}

Correlations between referents of happiness, PHI, and socio-demographic variables

\begin{tabular}{lcccc}
\hline & PHI & Sex & Age & $\begin{array}{c}\text { Educational } \\
\text { Level }\end{array}$ \\
\hline Stoicism & $-.10^{* *}$ & -.03 & .02 & $-.12^{* *}$ \\
Utopia & -.04 & -.04 & .03 & $.05^{*}$ \\
Tranquility & -.03 & -.03 & .04 & $-.08^{* *}$ \\
Enjoyment & $.05^{*}$ & -.04 & .03 & -.01 \\
Fulfillment & -.00 & -.02 & .03 & $.05^{*}$ \\
Satisfaction & $.05^{*}$ & $.05^{*}$ & $-.08^{* *}$ & .04 \\
Carpe Diem & .02 & -.03 & $-.07^{*}$ & .00 \\
Affiliation & $.10^{* *}$ & .00 & -.01 & .00 \\
\hline${ }^{*} p<.05 ;{ }^{* *} p<.001$. & & & &
\end{tabular}

The first hypothesis was confirmed; low educational level (see Table 2) was associated with the referents Stoicism and Tranquility, and a higher educational level correlated with Fulfillment (H2) but not with hedonism.

Concerning age, it was confirmed that young people agreed more with Satisfaction and Carpe Diem. Nevertheless, it was not confirmed that the older the person is, the more they agree with the referents Tranquility and Virtue.

Regarding the referents for happiness and well-being, hypothesis 5 was partially confirmed since Stoicism was associated to a lower wellbeing. In turn, Satisfaction, Affiliation, Enjoyment, and Carpe Diem were associated to a higher well-being. 


\section{Table 3}

Correlations between satisfaction with the sources of happiness, referents of happiness, and PHI.

\begin{tabular}{|c|c|c|c|c|c|c|c|c|}
\hline \multirow[b]{2}{*}{ Stoicism } & \multicolumn{2}{|c|}{ doing my job } & \multicolumn{2}{|c|}{$\begin{array}{l}\text { with my } \\
\text { family }\end{array}$} & \multicolumn{2}{|c|}{$\begin{array}{l}\text { with my } \\
\text { friends }\end{array}$} & \multicolumn{2}{|c|}{$\begin{array}{l}\text { with free } \\
\text { time }\end{array}$} \\
\hline & -.08 & $* *$ & -.17 & $* * *$ & -.05 & & .04 & \\
\hline Virtue & .01 & & -.03 & & -.03 & & -.04 & \\
\hline Utopia & .02 & & -.06 & & .01 & & -.02 & \\
\hline Tranquility & -.08 & $*$ & -.11 & $* * *$ & -.05 & & .00 & \\
\hline Fulfillment & -.00 & & -.09 & $* *$ & .01 & & .01 & \\
\hline Satisfaction & .05 & & .15 & $* * *$ & .06 & & -.02 & \\
\hline Carpe diem & -.02 & & -.06 & $*$ & -.01 & & .02 & \\
\hline Enjoyment & .00 & & -.02 & & -.07 & $*$ & -.05 & \\
\hline Affiliation & -.08 & $* *$ & .04 & & .06 & & .08 & $* *$ \\
\hline PHI & .37 & $* * *$ & .34 & $* * *$ & .24 & $* * *$ & .03 & \\
\hline
\end{tabular}

Regarding the relation between referents and sources for happiness, those who shared the referent Stoicism were less satisfied with the sources for happiness: they feel less happy with family (see Table 3), less satisfied with work, and less happy with friends. The participants who picked Tranquility felt less happy with family and less satisfied in work. People with the referent Satisfaction felt more satisfied with family and happier with friends than the participants who chose other referents. People who picked Affiliation were less satisfied with work, felt happier with friends, and more satisfied with time saved for leisure. The referent Virtue did not appear associated with the sources for happiness nor with the satisfaction level obtained in them, whereas Utopia was associated to feeling less happy with family. The referent Fulfillment was associated to a lower satisfaction with family, while Enjoyment 
was associated with feeling less happy with friends. Finally, it can be highlighted that satisfaction, regarding the sources for happiness, was significantly associated with the PHI, except for leisure.

\section{Regression Analysis}

Eight dummy variables were created with the referents for happiness and the referent Utopia was left as a contrast category. The expected value was calculated through multiplying satisfaction towards the source by its importance value. In a second model, expected values were added for the sources of happiness. The second model allowed us to contrast H6 and H7. In the third model, a predictor factor (the positive and negative feelings from the day before) was included to control the influence of affect or lived well-being (see Table 4).

According to Table 4, the first model explains $4.7 \%$ of the variance of the PHI scale and the second 21\%. The third model explains $28 \%$ of the variance. The second model significantly increases the explained variance by $16 \%, F(4,1044)=55.05, p=.001$. This model supports H6, that family is the most relevant source for general well-being (standardized beta or $\mathrm{B}=.20$ ). It also supports $\mathrm{H} 7$ or the idea of decreasing impact of the family, work $(\mathrm{B}=.12)$, and friends $(\mathrm{B}=.12)$ on the general well-being of participants. Leisure did not show a significant beta.

The third model also significantly increases the variance by $6.8 \%$, $F(2,1042)=49.68 ; p=.001$. The multivariate analysis confirms that controlling the satisfaction with the sources of happiness and the previous day's feelings, the referents Affiliation, Enjoyment, and Carpe Diem predict a higher remembered well-being. The referent Satisfaction was close to statistical significance. 


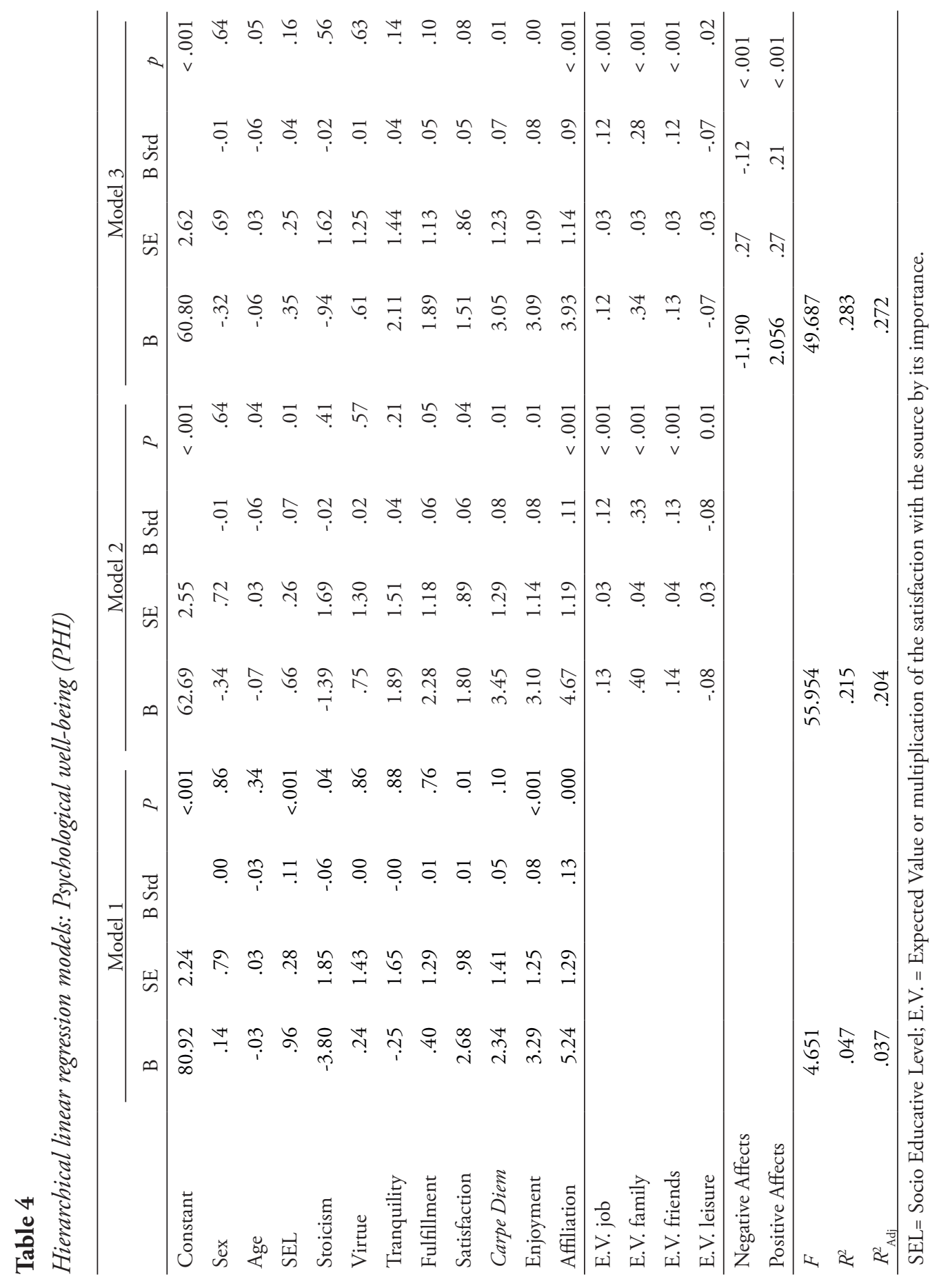


Psychological well-being and their relationship with different referents / Moyano-Diaz et al.

\section{Discussion}

In this study, it was found that the referent of happiness Satisfaction was the most shared by the population, 2 or 3 people out of 10, whereas Enjoyment, Carpe Diem, and Fulfillment were shared by a minority of 1 out of 10 participants. Even smaller groups shared Virtue and Tranquility.

It was confirmed that Stoicism and Tranquility were associated to a lower educational level in Chileans, as was found in the study with the Mexican population (Rojas, 2005). It is also confirmed that the higher the educational level, the higher the agreement was with the referent Fulfillment, which is akin to eudaimonia (well-being as personal growth) (Ryff et al., 2003). Results support the first two hypotheses that people with a higher educational level, income, and occupational status share more of a eudemonistic vision about well-being and less of a calm acceptance about life (Hernández et al, 2017). In turn, those people with a lower educational level and of a working-class status share a more collectivistic vision about happiness like calmness and self-control (Tsai \& Park, 2014). Finally, the emphasis on Satisfaction and Affiliation appeared to be transversal through the entire Chilean population.

The general results confirm that in the early stages of adulthood, people tend to 'live more in the moment' and they are more satisfied with what they have in this stage of life. Young people agreed more with the referents Carpe Diem and Satisfaction.

The relation between the conceptual referents for happiness and well-being shows that the Satisfaction is associated to and predicts a higher well-being (see also Rojas, 2005; Rojas \& Vitterso, 2010). Participants sharing this referent valued friends and family more as sources for happiness. It was confirmed that the referent Enjoyment was associated to and predicted a higher well-being, although people valued friends less as sources for happiness (see also Rojas, 2005 and Rojas \& Vitterso, 2010). Satisfaction and Enjoyment results support the idea that having a hedonistic conception about happiness, with emphasis 
on pleasure, the absence of pain, and the enjoyment of positive experiences, will direct people to experience higher well-being (Luybomirsky, 2008).

The positive association of the referent Carpe Diem and Tranquility with well-being were not confirmed with bivariate analyses. In samples of young people, this referent was also not associated to wellbeing (Rojas \& Vitterso, 2010).

The referent Stoicism was associated but did not predict a lower well-being in the multivariate analyses. This is congruent with the results from Rojas (2005) and with the content of self-control and its association to a lower educational level. This referent was associated to less agreement with the idea that happiness lies in social sources such as family, work, and friendship.

Finally, the referent Affiliation was chosen as important for 1 out of 10 people in this study; it appeared to be associated with a higher well-being of all kinds. Congruently, this referent was associated to putting more value on friends and leisure as main sources of happiness and less on work. This is the referent that shows the strongest multivariate coefficient, confirming the centrality of positive emotional relationships in the expressive and "sympathetic" collectivist culture of Latin America (Rojas, 2018; Fernández et al., 2000; Triandis et al., 1984).

Globally, results suggest that in Chilean culture referents that are focused on the relation of the person with the environment have more influence over their well-being. The importance of this relation with the social environment (more so than the inner-oriented) is coherent with the collectivist aspect of this culture. This is relevant for satisfaction in life, for instance, the social aspect and not the private facet of religiosity (Páez et al., 2017). In the collectivist cultures, happiness is framed from the social point of view; it emphasizes the Affiliation ideal in comparison to other individualistic cultures where the focus is the 'I' and the internal process is stronger (Diener \& Suh, 2000).

Results support that family is the most relevant source for general (PHI) well-being. As expected, the results show a decreasing influential impact of family, work, and friends. Family appears as the most impor- 
tant, probably because it fulfills the needs of positive relationships with others and the meaning of life (Moyano \& Ramos, 2007).

Overall, this study shows the importance of certain conceptual referents for happiness given that they predict well-being even when controlling relevant socio-demographic variables, satisfaction with the four main areas of human functioning, and the previous day's feelings. Results also demonstrated that referents for happiness showed a modest incremental validity of about $2-3 \%$ on well-being.

One limitation of this study was that the referent variable about happiness, was assessed using a dichotomy model by asking the participants to choose only one of the referents, following the initial standard procedure of Rojas (2005; 2007). Rojas \& Vitterso (2010) used an assessment method consisting of a Likert scale (agree-disagree) for each referent and could find stronger associations than with the samples using a happiness indicator (for instance, the average weighted correlation between satisfaction and happiness was of $r=.22$, against $r=.06$ in our case).

In future studies, it is advised to use a degree scale according to the referents for happiness. This study's procedure had the limitation of using a simple phrase for representing an ideal, framework, or referent for happiness. Similar procedures are used for studying the Schwartz values. These have the advantage that they can be applied to large samples of people that are not university students. Additionally, educational level was the simple indicator used for reflecting social status. Hence, it would be desirable to use more complex indicators that include income and occupational reputation in the future. Another important limitation is that this study is based on self-reports, in which some are retrospective, making it difficult to establish causal relationships. Nevertheless, although it is of convenience, the sample is broad and includes people of varied occupations, age, and educational levels similar to the general population. 


\section{References}

Costa, P. T., \& McCrae, R. R. (2006). Age changes in personality and their origins: Comment on Roberts, Walton, and Viechtbauer (2006). Psychological Bulletin, 132(1), 26-28. https://doi. org/10.1037/0033-2909.132.1.26

Diener E, Suh EM, eds. (2000). Culture and Subjective Well-Being. Cambridge, MA: MIT Press.

Fernández, I.; Carrera, P.; Sánchez, F.; Páez, D. y Candía, L. (2000). Differences between cultures in emotional verbal and non-verbal reactions. Psicothema, 12 (1): 83-92

Helliwell, J., Layard, R. \& Sachs, J. (2018) World Happiness Report.

New York: Sustainable Network.

Hernández, K., Muñoz, M., \& Moyano-Diaz, E. (2017). Concept of Happiness in Adults from Low-Income Class. Paidéia, 27(1), 386-394. https://doi.org/10.1590/1982-432727s1201703

Hervás, G., \&Vázquez,C.(2013).Constructionandvalidationofameasure of integrative well-being in seven languages: The Pemberton Happiness Index. Health and Quality of Life Outcomes, 11(1), 1-13. https://doi.org/10.1186/1477-7525-11-66

Hofstede, G., Hofstede, G.J., Minkov, M. (2010). Cultures and Organizations: Software of the Mind: Intercultural cooperation and its importance for survival (3rd Edition). New York: McGraw-Hill.

Kahneman, D. (2012). Pensar rápido, pensar lento. Barcelona: Cátedra. Luybomirsky, S. \& Lepper, H.S. (1999). A measure of subjective happiness: preliminary reliability and construct validation. Social Indicators Research, 46, 137-155 https://doi. org/10.1023/A:1006824100041

Luybomirsky, S. (2008). The how of happiness. New York: Penguin Press. Marshall, R. (1997). Variances in levels of individualism across two cultures and three social classes. Journal of Cross-Cultural Psychology, 28, 430-495. https://doi.org/10.1177/0022022197284007 
Moyano-Díaz, E., \& Ramos, N. (2007). Bienestar Subjetivo: Midiendo satisfacción vital, felicidad y salud en población chilena de la Región del Maule. Universum, 22(2), 184-200. https://doi. org/10.4067/S0718-23762007000200012

Moyano Díaz, E., Dinamarca, D., Mendoza-Llanos, R., \& PalomoVélez, G. (2018). Escala de Felicidad para Adultos (EFPA). Terapia Psicológica, 36(1), 33-45. https://doi.org/10.4067/ s0718-48082017000300033

Páez, D., Mendiburo Seguel, A. \& Martínez-Sánchez, F. (2013). Incremental validity of alexithymia, emotional coping and humor style on subjective and psychological well-being. Journal of Happiness Studies, 14, 1621-1637. https://doi.org/10.1007/ s10902-012-9400-0

Páez, D., Martínez-Zelaya, G, Bilbao, M., Vargas, S., Torres, J., Garcia, F. \& da Costa, S. (2017). Religiosity, psychosocial factors and well-being: A study in a representative Chilean sample. Psychology of Religion and Spirituality, 10(2), 138-145. https:// doi.org/10.1037/rel0000156

Ryff, C. D., Keyes, C. L. M. y Hughes, D. L. (2003) Status Inequalities, Perceived Discrimination, and Eudemonic Well- Being: Do the Challenges of Minority Life Hone Purpose and Growth? Journal of Health and Social Behavior, 44(3), 275-291. https://doi. org/10.2307/1519779

Rojas, M. (2005). A Conceptual-Referent Theory of Happiness: Heterogeneity and its consequences. Social Indicators Research, 74(2), 261-294. https://doi.org/10.1007/s11205-004-4643-8

Rojas, M. (2007). Heterogeneity in the relationship between income and happiness: A conceptual-referent-theory explanation. Journal of Economic Psychology, 28(1), 1-14. https://doi.org/10.1016/j. joep.2005.10.002

Rojas, M., Veenhoven, R. (2013). Contentment and Affect in the Estimation of Happiness. Social Indicators Research, 110, 415431. https://doi.org/10.1007/s11205-011-9952-0 
Rojas, M., \& Vittersø, J. (2010). Conceptual referent for happiness: Cross-country comparisons. Journal of Social Research \& Policy, 2, 103-116.

Rojas, M. (2018). Happiness in Latin America has social foundations. In J. Helliwell, R. Layard \& J. Sachs. World Happiness Report (pp. 114-146). New York: Sustainable Network.

Sobol-Kwapinska, M. (2013). Hedonism, fatalism and 'carpe diem': Profiles of attitudes towards the present time. Time \& Society, 22(3), 371-390. https://doi.org/10.1177/0961463X13487043

Springer, K. W., Pudrovska, T., \& Hauser, R. M. (2009). Does psychological well-baing change with age? : Longitudinal tests of age variations and further exploration of the multidimensionality of Ryff's Model of Psychological Well-Being. Social Science Research, 6(1), 247-253. https://doi.org/10.1111/j.1743-6109. 2008.01122.x. Endothelial

Triandis, H. C., Marín, G., Lisansky, J., \& Betancourt, H. (1984). Simpatía as a cultural script of Hispanics. Journal of Personality and Social Psychology, 47(6), 1363-1375. https://doi. org/10.1037/0022-3514.47.6.1363

Tsai, J., \& Park, B. (2014). The cultural shaping of Happiness. The role of Ideal Affect. In J. Gruber \& J. T. Moskowitz (Eds.), Positive Emotion: Integrating the Light Sides and Dark Sides (pp. 345-362). New York: Oxford University Press. https://doi.org/10.1093/ acprof:oso/9780199926725.003.0019

Wink,P.(1997). Beyondethnicdifferences: Contextualizingtheinfluence of ethnicity and individualism and collectivism. Journal of Social Issues, 53, 329-350. https://doi.org/10.1111/j.1540-4560.1997. tb02446.x

Recibido: 28/12/2019

Revisado: $15 / 06 / 2020$

Aceptado: 06/07/2020 